\title{
Symmetrical peripheral gangrene and disseminated intravascular coagulation associated with pelvi- ureteric junction obstruction
}

\author{
Victoria Louise Reid, James McLay
}

School of Medicine and Dentistry, University of Aberdeen, Aberdeen, UK

\section{Correspondence to} Dr Victoria Louise Reid, victoria.reid@nhs.net
To cite: Reid VL, McLay J. BMJ Case Reports Published online: [please include Day Month Year] doi:10.1136/ bcr-2012-006519

\section{DESCRIPTION}

An 87-year-old woman presented to the emergency department with confusion, sinus tachycardia, hypotension and fever. Laboratory investigations confirmed metabolic acidosis, acute kidney injury (urea $18.5 \mathrm{mmol} / \mathrm{l}$, serum creatinine $197 \mu \mathrm{mol} / \mathrm{l}$ and Egfr $21 \mathrm{ml} / \mathrm{min} / 1.73 \mathrm{~m}^{2}$ ), depressed bone marrow function (platelets $136 \times 10^{9} / 1$ and white cell count (WCC) $3.0 \times 10^{9} / 1$ ) and elevated prothrombin and activated partial thromboplastin time (PT $15.8 \mathrm{~s}$ and APTT $61 \mathrm{~s}$ ). Urinalysis was positive for blood, protein and leucocytes. Severe sepsis was diagnosed and treatment with intravenous fluids, co-amoxiclav and vitamin $\mathrm{K}$ was initiated. Proteus mirabilus was later identified from blood cultures.

Despite treatment the patient deteriorated with abdominal tenderness, refractory hypoglycaemia, mucocutaneous bleeding, symmetric areas of petechiae, ecchymotic plaques and dry gangrene of the upper and lower extremities (figures 1 and 2). Laboratory investigations suggested disseminated intravascular coagulation (DIC) (platelets $13 \times 10^{9} / 1$, PT $23.3 \mathrm{~s}$, APTT $68.5 \mathrm{~s}$ and normal fibrinogen). A vasculitis screen was negative. She was treated with intravenous tazocin, hydrocortisone and platelets. On day 7, CT imaging demonstrated left pelvi-ureteric junction (PUJ) obstruction, rupture of the left renal tract (figure 3) and multiple abdominal and pelvic fluid collections. A left-sided ureteric stent was inserted by the urologists, and the digits affected by dry gangrene were autoamputated under the plastic surgeons.

Symmetrical peripheral gangrene (SPG) is a rare, but devastating complication of DIC, characterised by SPG with no evidence of large-vessel occlusion or vasculitis. ${ }^{1}$ Microorganisms commonly implicated include meningococci, pneumococci, streptococci and staphylococci. ${ }^{2}$ To our knowledge, this is the first reported case of SPB caused by proteus spp. ${ }^{3}$

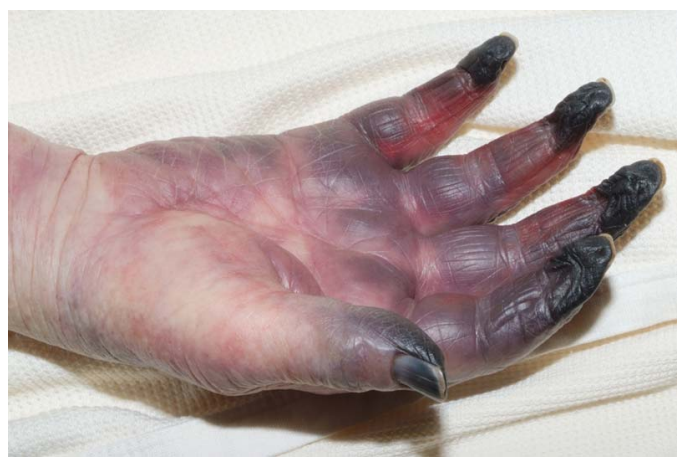

Figure 1 Bluish discoloration and ecchymotic plaques of the palm and fingers with dry gangrene of the distal phalanges.

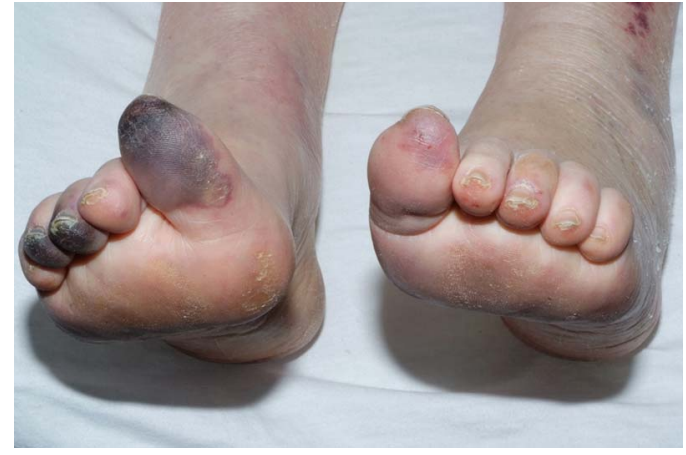

Figure 2 Petechiae, ecchymotic plaques and dry gangrene of the toes.

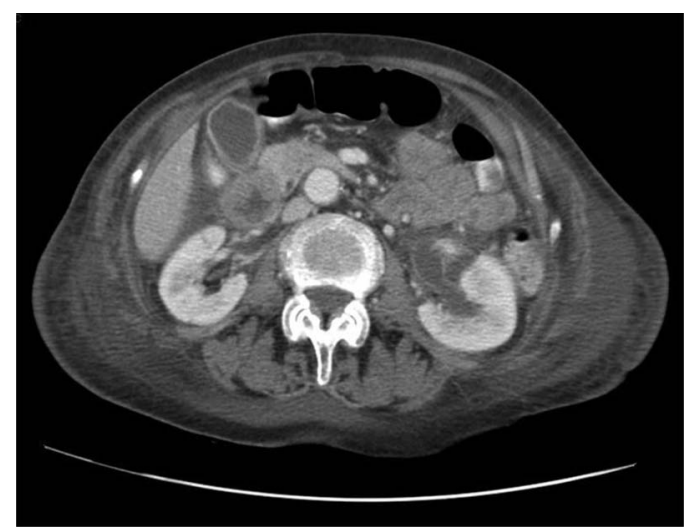

Figure $3 \mathrm{CT}$ imaging of the abdomen demonstrating a fluid collection extending from the lower pole of the left kidney, continuous with a dilated proximal ureter, consistent with left PUJ obstruction.

\section{Learning points}

- Symmetrical peripheral gangrene is a rare, but important, dermatological manifestation of disseminated intravascular coagulation.

- Gram-positive microorganisms are most commonly implicated, but Gram-negative bacilli have been reported.

- No treatment is universally effective and attention should be focused on correcting the underlying cause.

Competing interests None.

Patient consent Obtained.

Provenance and peer review Not commissioned; externally peer reviewed. 


\section{REFERENCES}

1 Davis M D, Byrd J, Lior T, et al. Symmetrical peripheral gangrene due to disseminated intravascular coagulation. Arch Dermatol 2001;137: $139-40$.
2 Molos M A, Hall J C. Symmetrical peripheral gangrene and disseminated intravascular coagulation. Arch Dermatol 1985;121:1057-61.

3 Rintala E, Kauppila M, Seppala OP, et al. Protein C substitution in sepsis-associated purpura fulminans. Crit Care Med 2000;7:2373-8.

Copyright 2013 BMJ Publishing Group. All rights reserved. For permission to reuse any of this content visit

http://group.bmj.com/group/rights-licensing/permissions.

BMJ Case Report Fellows may re-use this article for personal use and teaching without any further permission.

Become a Fellow of BMJ Case Reports today and you can:

- Submit as many cases as you like

- Enjoy fast sympathetic peer review and rapid publication of accepted articles

- Access all the published articles

- Re-use any of the published material for personal use and teaching without further permission

For information on Institutional Fellowships contact consortiasales@bmjgroup.com

Visit casereports.bmj.com for more articles like this and to become a Fellow 